\title{
Establishment and characterisation of six human biliary tract cancer cell lines
}

\author{
J-L Ku', K-A Yoon', I-J Kim', W-H Kim², J-Y Jang ${ }^{3}$, K-S Suh ${ }^{3}$, S-W Kim³, Y-H Park' ${ }^{3}$ J-H Hwang ${ }^{4}$, Y-B Yoon ${ }^{4}$ and \\ J-G Park*,1,5
}

'Laboratory of Cell Biology, Korean Cell Line Bank, Cancer Research Center and Cancer Research Institute, Seoul National University College of Medicine, Seoul I I0-744, Korea; ${ }^{2}$ Department of Pathology, Seoul National University College of Medicine, Seoul I 10-744, Korea; ${ }^{3}$ Department of Surgery, Seoul National University College of Medicine, Seoul I l 0-744, Korea; ${ }^{4}$ Department of Internal Medicine, Seoul National University College of Medicine, Seoul I I 0-744,

Korea; ${ }^{5}$ National Cancer Center, Madul-dong, Goyang, Gyeonggi 4II-764, Korea

Human cell lines established from biliary tract cancers are rare, and only five have been reported previously. We report the characterisation of six new six biliary tract cancer cell lines (designated SNU-245, SNU-308, SNU-478, SNU-869, SNU- 1079 and SNU-1196) established from primary tumour samples of Korean patients. The cell lines were isolated from two extrahepatic bile duct cancers (one adenocarcinoma of common bile duct, one hilar bile duct cancer), two adenocarcinomas of ampulla of Vater, one intrahepatic bile duct cancer (cholangiocarcinoma), and one adenocarcinoma of the gall bladder. The cell phenotypes, including the histopathology of the primary tumours and in vitro growth characteristics, were determined. We also performed molecular characterisation, including DNA fingerprinting analysis and abnormalities of K-ras, p/5, p/6, p53, hMLHI, hMSH2, DPC4, $\beta$-catenin, E-cadherin, hOGGI, STKII, and TGF- $\beta R / l$ genes by PCR-SSCP and sequencing analysis. In addition, we compared the genetic alterations in tumour cell lines and their corresponding tumour tissues. All lines grew as adherent cells. Population doubling times varied from $48-72 \mathrm{~h}$. The culture success rate was $20 \%$ (six out of 30 attempts). All cell lines showed (i) relatively high viability; (ii) absence of mycoplasma or bacteria contamination; and (iii) genetic heterogeneity by DNA fingerprinting analysis. Among the lines, three lines had p53 mutations; and homozygous deletions in both p/6 and p/5 genes were found three and three lines, respectively; one line had a heterozygous missense mutation in hMLHI; E-cadherin gene was hypermethylated in two lines. Since the establishment of biliary tract cancer cell lines has been rarely reported in the literature, these newly established and well characterised biliary tract cancer cell lines would be very useful for studying the biology of biliary tract cancers, particularly those related to hypermethylation of E-cadherin gene in biliary tract cancer.

British Journal of Cancer (2002) 87, 187 - 193. doi:10.1038/sj.bjc.6600440 www.bjcancer.com

(c) 2002 Cancer Research UK

Keywords: biliary tract cancer; cell line; cell culture; mutation; hypermethylation; E-cadherin

The prognosis of patients with biliary tract cancer is poor despite recent advances in diagnostic and therapeutic techniques (Yamada et al, 1995; Yoshida et al, 1995). An understanding of the biological nature of this neoplasm is needed to improve the prognosis of these patients. For this purpose, a permanently growing cell line can be the most suitable tool because it is applicable to a variety of experiments, including the understanding of tumour biology (Yano et al, 1992; Yamada et al, 1995). However, biliary tract cancer cell lines are very rare, a total of 13 cell lines have been reported in the literature. Gene alterations involving in carcinogenesis and cancer progress in the cancers of alimentary tract such as colorectal cancer and pancreatic cancer have been known. However, in biliary tract cancers, few reports have shown genetic changes responsible for oncogene and tumour suppressor gene (Yoshida et al, 1995). In the present study, we report the establishment and characterisation of six new human biliary tract

*Correspondence: JG Park, Laboratory of Cell Biology, Cancer Research Institute, Seoul National University College of Medicine, 28 Yongon-dong, Chongno-gu, Seoul, I I0-744, Korea; E-mail: jgpark@plaza.snu.ac.kr

Received 24 December 200I; revised I5 April 2002; accepted 8 May 2002 cancer cell lines (designated SNU-245, SNU-308, SNU-478, SNU-869, SNU-1079 and SNU-1196). We described cell phenotypes including the in vivo and in vitro growth characteristics, and DNA profiles for authenticity of each line. We also checked genetic alterations of K-ras, p15, p16, p53, hMLH1, hMSH2, DPC4, STK11, E-cadherin, hOGG1, TGF- $\beta R I I$ genes and compared the genetic alterations in tumour cell lines and their corresponding tumour tissues. In these biliary tract cancer cell lines, the methylation status of promoter region in E-cadherin gene was also investigated by 5 -aza-2'-deoxycytidine treatment and methylation specific-polymerase chain reaction (MS-PCR) after sodium bisulphite treatment.

\section{MATERIALS AND METHODS}

\section{Cell culture}

Cell lines were established from pathologically proven primary biliary tract and ampulla of Vater cancer samples of six Korean patients. Of these, two cancer cell lines originated in extrahepatic bile duct cancer, one in intraheatic bile duct cancer, and one in adenocarcinoma of gall bladder, and two in ampulla of Vater 
cancer. Solid tumours were finely minced with scissors and disassociated into small aggregates by pipetting. Appropriate amounts of finely minced neoplastic-tissue fragments were seeded into $25 \mathrm{~cm}^{2}$ flasks. Tumour cells were initially cultured in ACL-4 medium supplemented with 5\% heat-inactivated foetal bovine serum (AR5) (Park et al, 1987, 1995). After establishment, cultures were maintained in RPMI 1640 supplemented with $10 \%$ heatinactivated foetal bovine serum. If stromal-cell growth was noted in initial cultures, differential trypsinisation was used to obtain a pure tumour-cell population. Cultures were maintained in humidified incubators at $37^{\circ} \mathrm{C}$ in an atmosphere of $5 \% \mathrm{CO}_{2}$ and $95 \%$ air. A-431, HeLa, and K-562 cell lines from the American Type Cell Culture (ATCC) and SNU-1 cell line from Korean Cell Line Bank (KCLB) were used for PCR controls. For growth properties and morphology study in vitro, population doubling times and cell viability were determined and cells grown on $75-\mathrm{cm}^{2}$ culture flasks were observed daily by phase-contrast microscopy (Park et al, 1995).

\section{Nucleic acid isolation, cDNA synthesis and DNA profiles}

Genomic DNA and total RNA were isolated from washed-cell pellets. cDNA was synthesised according to the manufacturer's specifications (Power cDNA synthesis kit; Intron Biotechnology, Seoul, Korea) using $2 \mu \mathrm{g}$ of total RNA. To compare the genetic alterations between established tumour cell lines and their corresponding tumour tissues, we obtained DNAs from microdissected tumour cells and stromal cells in H\&E stained slides of corresponding tumour tissues of each tumour cell line. Approximately $500-$ 1000 dissected tumour or stromal cells were digested using proteinase K method described previously (Hung et al, 1995). For DNAprofile analysis, DNA was amplified by PCR at loci containing highly polymorphic microsatellite markers: D1S1586 and D3S1765 (Ku et al, 1999).

\section{Mutation screening in K-ras, p53, p15, p16, hMLH1 and hMSH2 genes}

Mutation screening of exons 1 and 2 of $\mathrm{K}$-ras was performed by DNA sequencing analysis using oligonucleotide primers as previously described (Capon et al, 1983). Mutational screening of exons 5 to 8 of $p 53$ was performed by PCR-based single strand conformation polymorphism (PCR-SSCP) analysis (Kang et al, 1996). Primers for PCR-SSCP for exons 1 and 2 of the p15 gene were synthesised (Orlow et al, 1995), and PCR-SSCP primers for exons 1 and 2 of p16 gene were carried out as described previously (Williamson et al, 1995). For deletion analysis of the p15 and p16 genes, we amplified the exons of each gene without $\left[\alpha^{32} \mathrm{P}\right]$-dCTP. To investigate the genetic status of $h M S H 2$ and $h M L H 1$ genes in biliary tract cancer cell lines, PCR-SSCP analysis was used to screen mutations (Liu et al, 1994; Han et al, 1996).

\section{Mutation screening in $\beta$-catenin, DPC4, STK11, TGF- $\beta$ RII, and hOGG1 genes}

PCR-SSCP analysis to screen mutations of the $\beta$-catenin gene was carried out by designed-primers for amplification of exons 3, 5, and 6 , since mutations reported earlier in the $\beta$-catenin gene are concentrated at these exons (Kitaeva et al, 1997; Iwao et al, 1998). To investigate the genetic alteration of the DPC4 gene, we screened 11 exons by PCR-SSCP (Hahn et al, 1998). For mutational analysis of STK11 gene, the PCR primer pairs were used as described previously (Jenne et al, 1998). Mutation screening of the full seven exons of TGF- $\beta R I I$ gene was also performed by PCR-SSCP analysis (Lu et al, 1996). For mutational analysis of hOGG1 gene, PCR primer pairs and conditions were described previously (Kohno et al, 1998).

\section{Genetic alteration and methylation analysis of E-cadherin gene}

To investigate mutation, all 16 exons were screened by PCR-SSCP (Berx et al, 1996). For determination of the methylation status in E-cadherin gene, 5-aza-2'-deoxycytidine treatment and sodium bisulphite modification were employed. For 5-aza-2'-deoxycytidine treatment, cells were seeded at $2 \times 10^{5}$ cells $75-\mathrm{cm}^{2}$ culture flask on day 0 . The cells were treated with $10 \mu \mathrm{m} \mathrm{5-aza-2'-deoxycytidine} \mathrm{for}$ $24 \mathrm{~h}$ on days 2 and 5 . The medium was changed $24 \mathrm{~h}$ after adding 5 -aza- $2^{\prime}$-deoxycytidine. Cells were harvested on day 8 for analysis of E-cadherin expression.

For mRNA expression analysis, cDNA was amplified in a $25 \mu \mathrm{l}$ PCR reaction using $0.75 \mu \mathrm{l}$ of the reverse-transcription reaction, the primers and 0.5 units of the Taq DNA polymerase. Both Ecadherin and $\beta$-actin $\mathrm{RT}-\mathrm{PCR}$ reactions used the same cDNA synthesis. $\beta$-actin was amplified to control for RNA integrity. The primers for the amplification of E-cadherin gene mRNA were described previously (Melki et al, 2000). Products were electrophoresed on a $2 \%$ agarose gel with ethidium bromide.

The sodium bisulphite reaction was carried out for $16 \mathrm{~h}$ at $55^{\circ} \mathrm{C}$. Following bisulphite modification, the DNA was ethanol precipitated, dried, and resuspended in $100 \mu \mathrm{l}$ distilled water. A nested PCR was performed using the nested PCR primers as described previously (Melki et al, 2000).

\section{Cloning and sequencing}

Samples showing abnormal bands by SSCP were subjected to DNA sequencing analysis. Fresh PCR products were ligated into $\mathrm{PCR}^{\mathrm{TM}} \mathrm{II}$ vectors and subcloned using the TA cloning system (Invitrogen, San Diego, CA, USA). A minimum of 10 individual clones were then pooled and used for DNA isolation. Bi-directional DNA sequencing analysis performed by using dideoxy chain termination method with a T7 DNA polymerase sequencing kit (Pharmacia Biotech Inc., Piscataway, NJ, USA), or directly sequenced using a Taq dideoxy terminator cycle sequencing kit on an ABI 377 DNA sequencer (Perkin-Elmer, Foster City, CA, USA).

\section{RESULTS}

\section{Culture characteristics}

Population doubling times ranged 48 to $72 \mathrm{~h}$, and cell viability ranged from 85 to $94 \%$ (Table 1). All the cell lines were free of contamination with either bacteria or Mycoplasma. The culture success rate was $20 \%$ (six out of 30 attempts).

\section{Morphologic studies}

Six carcinoma cell lines derived from biliary tract system were established. The primary tumour of SNU-245 originated from the distal common bile duct. Microscopically, the tumour was composed of well-formed glands lined by a few rows of highly atypical cuboidal cells with lumina containing oeosinophilic material or necrotic cell debris and infiltrated to the stroma. Cell line SNU-308 was established from an adenocarcinoma of a gall bladder. Microscopically, the tumour was composed of well-differentiated neoplastic glands or trabeculae. Two cases of ampulla of Vater carcinoma were obtained from primary tumours. Microscopically, the tumour of SNU-478 was poorly differentiated adenocarcinoma with signet ring cell feature and infiltrated to the pancreas along the interstitial space as a single cell or cell cords. The tumour of SNU-869 was composed of well differentiated adenocarcinoma with focal papillary feature. Five out of 10 periduodenal lymph nodes were involved by this tumour and the tumour infiltrated to the duodenal muscle layer and involved of 
Table I In vivo and in vitro characteristics of biliary tract cancer cell lines

\begin{tabular}{|c|c|c|c|c|c|c|c|c|c|}
\hline \multirow[b]{2}{*}{$\begin{array}{l}\text { Cell } \\
\text { line }\end{array}$} & \multicolumn{3}{|c|}{ In vivo } & \multicolumn{5}{|c|}{ In vitro } & \multirow[b]{2}{*}{$\begin{array}{l}\text { Prior } \\
\text { chemotherapy }\end{array}$} \\
\hline & Origin $^{a}$ & $\begin{array}{l}\text { Degree of } \\
\text { differentiation }\end{array}$ & $\begin{array}{l}\text { Nodal } \\
\text { status }^{b}\end{array}$ & $\begin{array}{l}\text { Growth } \\
\text { characteristics }^{c}\end{array}$ & $\begin{array}{c}\text { Viability } \\
\text { (\%) }\end{array}$ & $\begin{array}{l}\text { Doubling } \\
\text { time (h) }\end{array}$ & $\begin{array}{l}\text { Cell } \\
\text { morphology }\end{array}$ & $\begin{array}{l}\text { Nuclear } \\
\text { morphology }\end{array}$ & \\
\hline SNU-245 & CBD & Well & 0/9 & Ad & 85 & 54 & Polygonal & Single & None \\
\hline SNU-308 & GB & Moderately & - & Ad & 88 & 48 & Polygonal & Single & None \\
\hline SNU-478 & AV & Poorly & $0 / 8$ & Ad & 83 & 52 & Polygonal/spherical & Single/multiple & None \\
\hline SNU-869 & AV & Well & $5 / 10$ & Ad & 91 & 48 & Polygonal & Single & None \\
\hline SNU-1079 & IHD & Moderately & - & Ad & 89 & 72 & Pleomorphic & Single/multiple & None \\
\hline SNU-1196 & HDB & Moderately & $0 / 1$ & $\mathrm{Ad}$ & 94 & 48 & Spindle to polygonal & Single & None \\
\hline
\end{tabular}

${ }^{\mathrm{a}} \mathrm{CBD}=$ common bile duct, $\mathrm{GB}=$ gall bladder, $\mathrm{AV}=$ ampulla of Vater, $\mathrm{HD}=$ =intrahepatic duct, $\mathrm{HDB}=$ hepatic duct bifurcation. ${ }^{\mathrm{b}} \mathrm{Metastasis/total.}{ }^{\mathrm{c}} \mathrm{Ad}=\mathrm{adherent.}$

distal common bile duct. The case of SNU-1079 was obtained from the cholangiocarcinoma arising from right lobe of liver. Microscopically, the tumour of SNU-1079 was composed of irregular nests of tumour cells with focal glandular differentiation, which were separated by fibrous stroma. Cell line SNU-1196 was derived from Klatskin tumour arising in the hepatic duct confluence and invaded to the both intrahepatic duct and common bile duct. Tumour cells had large and vesicular nuclei, and micro or macronucleoli.

In culture, all the cell lines except SNU-478 grew as monolayer of substrate-adherent cells. SNU-245 exhibited trabecular arrangement with acinar formation (Figure 1A). Tumour cells of SNU308 was composed of polygonal and relatively uniform cells having large, round to ovoid, vesicular nuclei with prominent nucleoli. Acinar formation was focally seen (Figure 1B). SNU-478 showed two distinct growth pattern, The cells growing as monolayer were polygonal, and cells growing as spherical cells in suspension formed grape-like clusters. The polygonal adherent cells of SNU-478 showed large, round to ovoid, vesicular nuclei with several nucleoli (Figure 1C). SNU-869 composed of polygonal adherent cells grew confluently with frequent acinar formation and floating clumps of tumour cells. SNU-1079 exhibited marked pleomorphic appearance with multiple cytoplasmic processes. Multinucleated bizarre tumour cells were frequently seen. Some cells had numerous cytoplasmic vacuoles. SNU-1196 forming trabecular pattern consisted of spindle to polygonal shaped cells having vesicular nuclei and multiple small nucleoli.

\section{DNA profiles}

DNA profiles using two highly polymorphic microsatellite markers (D1S1586 and D3S1765) showed that six biliary tract carcinoma cell lines are unique and unrelated (Figure 2). These results help exclude the possibility of cross-contamination between the cell lines, as well as by HeLa cell line.

\section{Mutations in the $p 53, p 15, p 16$ and $h M L H 1$ genes}

For $p 53$ gene, SNU-478 had an adenine insertion at codon 266 of exon 8 resulting in a premature stop codon (TGA) at 12 bp downstream (Figure 3): SNU-869 harboured a missense mutation from aspartic (GAC) acid to glycine (GGT) at codon 48 of exon 4; SNU-1196 had a missense mutation from asparagine (CGT) to cysteine (TGT) at codon 273 of exon 8 . A summary of the results appears in Table 2.

There were no band shifts in p15 and p16 genes by PCR-PCR SSCP analysis. However, there were no PCR amplifications in three lines (SNU-478, SNU-1079, and SNU-1196). By based deletion analysis of each gene, we found that exon 1 of p15 gene was not amplified in three cell lines (SNU-478, SNU-1079 and SNU$1196)$ and exon 2 of this gene was not amplified in two cell lines (SNU-478 and SNU-119). We also found that exons 1 and 2 of p16 gene were not amplified in three cell lines (SNU-478, SNU-1079 and SNU-1196) (Figure 4). The results were listed (Table 2).
In $h M L H 1$ mutational analysis, only SNU-478 harboured a heterozygous missense mutation from GAT to GTT at codon 384 of exon 12, with resultant amino acid change from aspartic acid to valine (data not shown).

\section{Mutation analysis in $\beta$-Catenin, DPC4, hOGG1, STK11, and TGF- $\beta$ RII genes}

There were no abnormal band shift bands in the $\beta$-catenin, DPC4, STK11, and TGF- $\beta$ RII genes by PCR-SSCP analysis. In hOGG1 gene, 4 lines (SNU-308, SNU-478, SNU-869 and SNU-1079) were found to harbour abnormal band shift bands in exon 5. By the direct sequencing of DNA fragments corresponding to shifted bands, a $\mathrm{C} \rightarrow \mathrm{G}$ nucleotide change at $-15 \mathrm{bp}$ from exon 5 was found in all four lines (Table 2).

\section{mRNA expression and methylation analysis in E-cadherin gene}

By PCR-SSCP for all 16 exons, abnormal band shifts were not found in all cases. To determine the expression of E-cadherin gene in six biliary tract cancer cell lines, we used RT-PCR analysis. SNU-1 and A-431 cell lines were used for negative and positive controls for the expression of E-cadherin mRNA. As shown in Figure 5, SNU-245, SNU-308, SNU-869, SNU-1196 and control (A-431) cell lines expressed E-cadherin mRNA, whereas SNU-478, SNU-1079 and control (SNU-1) cell lines showed absence of expression (Figure 5A). Therefore, we determined the methylation status by 5 -aza-2'-deoxycytidine treatment and sodium bisulphite modification in these cell lines. After 5-aza-2'-deoxycytidine treatment, E-cadherin mRNA was reexpressed in SNU-478, SNU-1079 and control (SNU-1) cell lines (Figure 5B). Methylation specific PCR analysis for CpG island of promoter region in the E-cadherin gene after sodium bisulphite modification, DNA fragments were amplified in only SNU-478, SNU-1079 and SNU-1 cell lines (Figure 5C).

\section{Comparison of genetic alterations in tumour cell lines and their corresponding tumour tissues}

Of six biliary tract cancer cell lines, paraffin blocks from four cell lines (SNU-245, SNU-308, SNU-869 and SNU-1079) were available. Tumour cells and stromal cells were dissected, respectively, and DNAs were extracted from these samples. Genetic alterations in DNA of tumour cells were identical to those that had found in tumour cell lines and there were no mutations in constitutional DNAs (data not shown).

\section{DISCUSSION}

Advances in cell culture methods have made it possible to establish a variety of human carcinoma cell lines from surgical and autopsy tissues, peritoneum effusion, and biopsy specimens (Yano et al, 

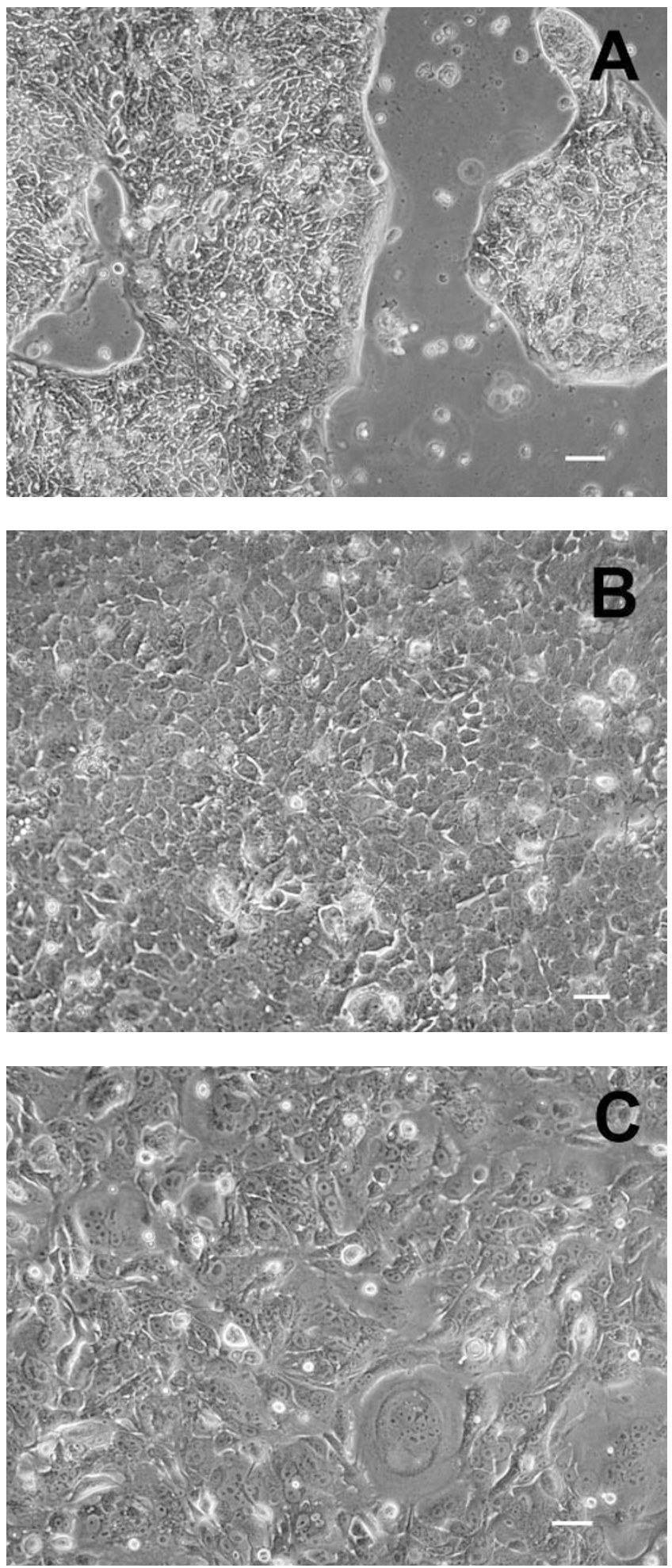

Figure I (A) Cultured cells of SNU-245 are polygonal shaped adherent cells and arranged in a trabecular pattern with acinar formation. (B) Phasecontrast microscopy of SNU-308 cell lines showed polygonal shaped adherent cells with large, round to ovoid, and vesicular nuclei. (C) Cultured cells of SNU-478 showed two distinct growth groups: the one growing as a monolayer is polygonal, and the other growing as spherical cells in suspension forms grape-like clusters. Scale bars $=50 \mu \mathrm{M}$.

1992; Yamada et al, 1995). Moreover, because pure cells in cultures can be used for a variety of studies that cannot be carried out using tissue specimens, the study of permanent cell lines established form
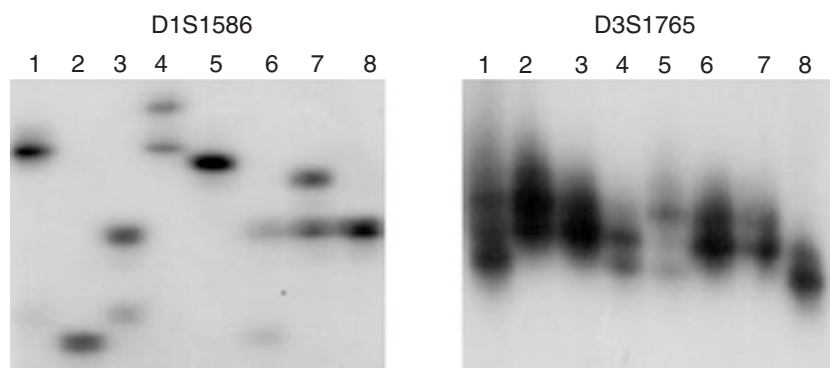

Figure 2 DNA fingerprinting analysis of biliary tract cancer cell lines using highly polymorphic microsatelilte markers. Lane numbers I to 8 show cell lines SNU-245, SNU-308, SNU-478, SNU-869, SNU- I079, SNU- I I96, HeLa, K-562, and water only. It is evident that each of the six SNU biliary tract cancer cell lines is unique and unrelated.
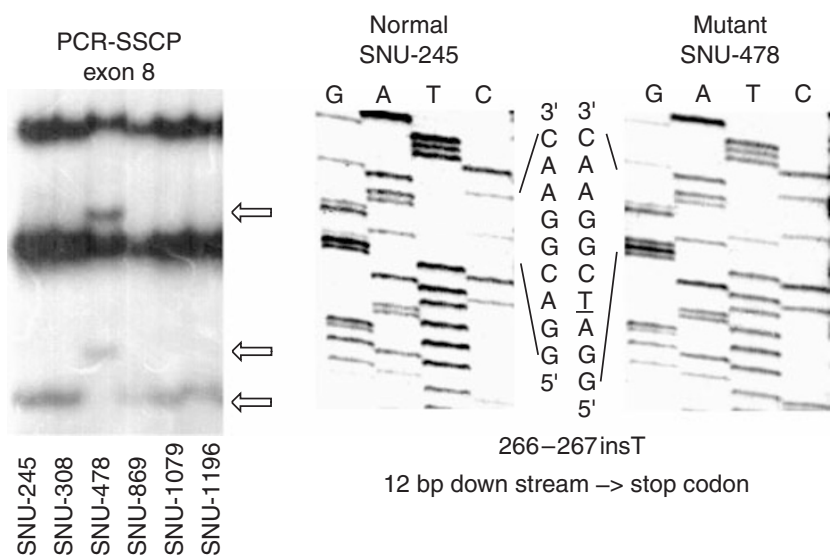

12 bp down stream $\rightarrow$ stop codon

Figure 3 PCR-SSCP and DNA sequencing analysis of exon 8 in the p53 gene. (left) PCR-SSCP analysis of exon 8 . Arrows indicate the shifted bands in SNU-478, as compared with the normal mobility in other cell lines. (right) DNA sequencing analysis of SNU-478.

human cancers has played a major role in our understanding of the biology of cancers. However, cell lines originated from biliary tract cancers have rarely been reported. Ten human extrahepatic bile duct carcinoma cell lines (SK-ChA-1 (Knuth et al, 1985), KMBC (Yano et al, 1992), and OCUCh-LM1 (Yamada et al, 1995), TFK-1 (Saijyo et al, 1995), ICBD-1 (Takiyama et al, 1998), HBDC (Jiao et al, 2000), SCK, JCK, Cho-CK, Choi-CK (Kim et al, 2001a)) and three gall bladder carcinoma cell lines (MZ-ChA-1 and MzChA-2 (Knuth et al, 1985), OCUG-1 (Yamada et al, 1997) have been reported in the world literature.

In this paper, we present six newly established biliary tract cancer cell lines derived from histopathological varied primary carcinomas including a distal common bile duct, gallbladder, two ampulla of Vater, an intrahepatic duct, and a hepatic duct bifurcation tumour. The culture success rate of $20 \%$, reflecting the relative high efficiency of AR5 medium in selective growth of human biliary tract cancers, although the establishment of cell lines from biliary tract cancers, especially cell lines from primary tumours, is very difficult as described above.

Primary tumours revealed morphological heterogeneity including cellular and a growth pattern of original tumours in each tumour type. Cell lines derived from primary biliary tract cancer showed marked heterogeneity in cellular and nuclear morphology, and growth pattern in vitro. All six cell lines grew as adherent monolayer, of these, SNU-869 formed prominent domes.

In biliary tract cancers, the role of p53 is still controversial and mutation rate of this gene varied from 33 to $65 \%$ according to 
Table 2 Abnormalities of the p/5, p /6, p53, K-ras, hMLHI, E-cadherin, hOGGI, $\beta$-catenin, DPC4, STKI I and TGF- $\beta$ RII genes in SNU biliary tract cancer cell lines

\begin{tabular}{|c|c|c|c|c|c|c|c|c|c|c|}
\hline \multirow{2}{*}{$\begin{array}{l}\text { Cell } \\
\text { line }\end{array}$} & \multirow[b]{2}{*}{ pl5 gene } & \multirow[b]{2}{*}{ pl6 gene } & \multirow[b]{2}{*}{ p53 gene } & \multirow{2}{*}{$\begin{array}{l}\text { K-ras gene } \\
\text { (exon I) }\end{array}$} & \multirow[b]{2}{*}{ MLHI gene } & \multicolumn{4}{|c|}{ E-cadherin } & \multirow[b]{2}{*}{ hOGGI } \\
\hline & & & & & & Mutation & Expression & 5-aza & MS-PCR & \\
\hline SNU-245 & WT & WT & WT & WT & WT & WT & + & + & - & WT \\
\hline SNU-308 & WT & WT & WT & WT & WT & WT & + & + & - & IVS4-|5C>G \\
\hline SNU-478 & Deletion & Deletion & 266-267ins $T$ & WT & Asp384Val & WT & - & + & + & IVS4- I5C>G \\
\hline SNU-869 & WT & WT & Asp48Gly & WT & WT & WT & + & + & - & IVS4-|5C>G \\
\hline SNU- 1079 & Deletion (exon I) & Deletion & $\mathrm{WT}$ & WT & WT & WT & - & + & - & IVS4-|5C>G \\
\hline SNU-I196 & Deletion & Deletion & Arg273Cys & WT & WT & WT & + & + & + & WT \\
\hline
\end{tabular}

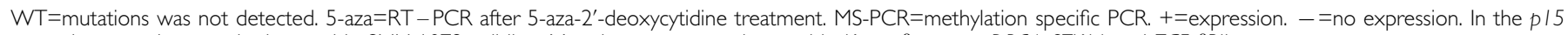
gene, the exon I was only detected in SNU- 1079 cell line. Mutations were not detected in K-ras, $\beta$-catenin, DPC4, STKII and TGF- $\beta$ RII genes.

(A) Exon 1

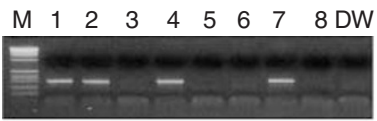

(B) Exon 2

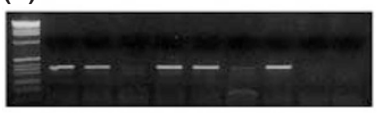

(C) K-ras

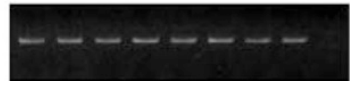

(D) Exon 1

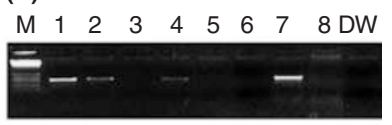

(E) Exon 2

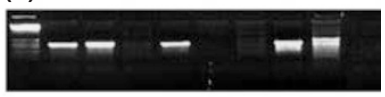

(F) K-ras

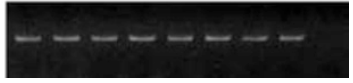

Figure 4 PCR-based deletion analysis of the $p / 5$ and $p / 6$ genes. $(\mathbf{A}, \mathbf{B})$ PCR amplification of the p/ 5 gene. (C) PCR amplification of exon 2 in the K-ras gene used as internal control for separate PCR amplification. (D,E) PCR amplification of the p/6 gene. (F) K-ras gene for internal control for separate PCR amplification. Lane numbers I to 9 show cell lines SNU-245, SNU-308, SNU-478, SNU-869, SNU-1079, SNU-I196, HeLa, $\mathrm{K}-562$, and water only.

anatomical site of the biliary tract. In gallbladder carcinomas from Korean, it was reported that $35.7 \%$ had mutations in this gene (Kim et al, 2001b). In newly established six cell lines, we detect two missense mutations and one frameshift mutation (50\%). Two mutations were found to be in exon 8 and one mutation in exon 4 .

p15 and p16 genes belonging to the cyclin-dependent kinase 4 inhibitory family, have homology and are adjacent to each other. In our six cell lines, simultaneously homozygous deletions of $p 15$ and $p 16$ genes, but no point mutation, were found in (SNU-478, SNU-1079 and SNU-1196). In SNU-1079, exon 1 of $p 15$ gene was deleted and exon 2 was intact. These results indicate that $p 15$ and $p 16$ are homozygously deleted preferentially in the region neighbouring the two genes in biliary tract cancer cell lines. Kim et al (2001) reported that $30.7 \%$ of this gene was mutated in gall bladder carcinomas from Korean. Moreover, the high frequency of deletions of $p 15$ and $p 16$ in cell lines indicate the possibility of these genes functioning as tumour suppressor genes in biliary tract cancer as described previously (Yoshida et al, 1995).

We also found one heterozygous missense mutation at codon 384 of exon 12 in hMLH1 gene in one cell line (SNU-478). We screened the microsatellite instability (MSI) status in this line using several MSI markers such as BAT-25, BAT-26 and BAT-40 which were used as a surrogate to indicate MSI status, but failed to find evidence of MSI (Myeroff et al, 1995). Although we didn't check this mutation in normal counterpart because of no availability normal tissue, we think that this mutation is polymorphism because this cell line did not show MSI.

A significant number of human carcinomas and cancer cell lines lose sensitivity to negative growth regulation by transform-

(A) RT-PCR for E-cadherin
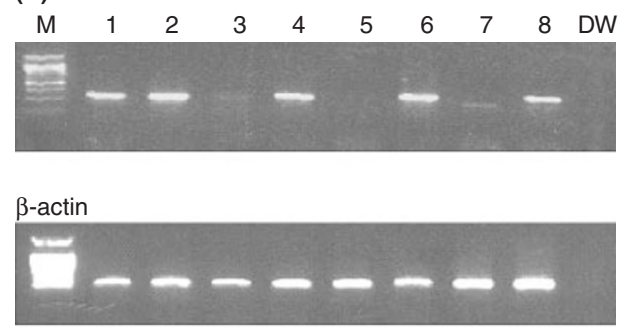

(B) RT-PCR after 5-azacytidine treat

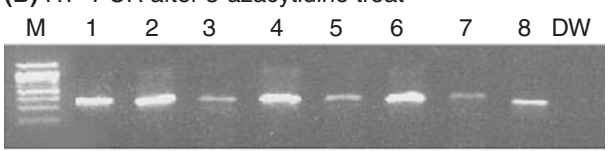

$\beta$-actin

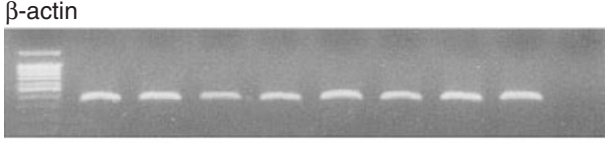

(C) Methylation specific PCR

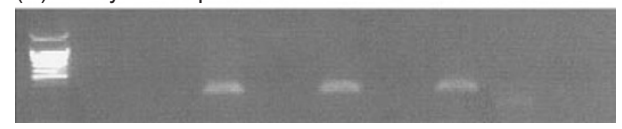

Figure 5 Hypermethylation of E-cadherin gene in SNU-biliary tract cancer cell lines. (A) RT-PCR analysis of E-cadherin gene. Lane numbers ( I -9) indicate cell lines: SNU-245, SNU-308, SNU-478, SNU-869, SNU1079, SNU- I 196, SNU-I (gastric carcinoma cell line, positive control for methylation of E-cadherin gene, A-43I (negative control), and water only. $\beta$-actin is RT-PCR control for mRNA expression. (B) RT-PCR analysis after 5-aza-2'-deoxycytidine treatment. It is note that E-cadherin gene is re-expressed after 5 -aza- 2 -deoxycytidine treatment. $\beta$-actin is RT-PCR control for mRNA expression. (C) Methylation specific PCR analysis after sodium bisulphite modification. It is evident that SNU-478 and SNU- 1079 lines are methylated in CPG island of promoter region in the E-cadherin gene.

ing growth factor $\beta$ (TGF- $\beta$ ) (Vincent et al, 1997). In biliary tract cancers, it was reported that $16 \%$ (five out of 32 primary biliary carcinomas) had point mutations in the DPC4 gene (Hahn et al, 1998). In our cell lines, we had not found shifted bands in all samples by PCR-SSCP analysis. Moreover, we found that all cell lines expressed intact DPC4 mRNA (data not shown). In addition, we did not find genetic alterations in TGF- $\beta R I I$ gene by PCR-SSCP and RT-PCR analysis, although genetic alterations of the TGF- $\beta R I I$ gene in biliary tract cancers have been reported 
in some (Goggins et al, 1998; Yazumi et al, 2000). We think that our results in six cancer cell lines do not relfect differences in genetics of biliary tract cancers in Korean because the sample size is too small, although we did not found any reports about mutations of DPC4 and TGF- $\beta R I I$ genes in biliary tract cancers in Korean.

E-cadherin gene on chromosome 16q22.1 encodes a protein product important in the maintenance of the epithelial phenotype mediated by a $\mathrm{Ca}^{2+}$-dependent, homotypic cell-cell adhesion. The gene has been termed a 'metastasis suppressor' gene, because the Ecadherin protein can suppress tumour cell invasion and metastasis. E-cadherin gene expression is reduced or silenced in carcinomas of the breast and liver and many cell lines including those from colon, stomach, and prostate (reviewed by Melki et al, 2000). Alterations in DNA methylation patterns are commonly found in essentially all cancers, often with concomitant changes in gene expression. In our study, we have not found mutations in all 16 exons of E-cadherin gene by PCR-SSCP. However, we found that E-cadherin gene expression was silenced in two cell lines (SNU-478 and SNU-

\section{REFERENCES}

Berx G, Cleton-Jansen AM, Strumane K, de Leeuw WJ, Nollet F, van Roy F, Cornelisse C (1996) E-cadherin is inactivated in a majority of invasive human lobular breast cancers by truncation mutations throughout its extracellular domain. Oncogene 13: 1919-1925

Capon DJ, Seeburg PH, McGrath JP, Hayflick JS, Edman U, Levinson AD, Goeddel DV (1983) Activation of Ki-ras2 gene in human colon and lung carcinomas by two different point mutations. Nature 304: 507-513

Goggins M, Shekher M, Turnacioglu K, Yeo CJ, Hruban RH, Kern SE (1998) Genetic alterations of the transforming growth factor beta receptor genes in pancreatic and biliary adenocarcinomas. Cancer Res 58: 5329-5332

Hahn SA, Bartsch D, Schroers A, Galehdari H, Becker M, Ramaswamy A, Schwarte-Waldhoff I, Maschek H, Schmiegel W (1998) Mutations of the DPC4/Smad4 gene in biliary tract carcinoma. Cancer Res 58: 1124-1126

Han HJ, Yuan Y, Ku JL, Oh JH, Won YJ, Kang KJ, Kim KY, Kim S, Kim CY, Kim JP, Oh NG, Lee KH, Choe KJ, Nakamura Y, Park J-G (1996) Germline mutations of hMLH1 and hMSH2 genes in Korean hereditary nonpolyposis colorectal cancer. J Nation Cancer Inst 88: 1317-1319

Hung J, Kishimoto Y, Sugio K, Virmani A, McIntire DD, Minna JD, Gazdar AF (1995) Allele-specific chromosome 3p deletions occur at an early stage in the pathogenesis of lung carcinoma. J Am Med Assoc 273: 558-563

Iwao K, Nakamori S, Kameyama M, Imaoka S, Kinoshita M, Fukui T, Ishiguro S, Nakamura Y, Miyoshi Y (1998) Activation of the beta-catenin gene by interstitial deletions involving exon 3 in primary colorectal carcinomas without adenomatous polyposis coli mutations. Cancer Res 58: $1021-1026$

Jenne DE, Reimann H, Nezu J, Friedel W, Loff S, Jeschke R, Muller O, Back W, Zimmer, M (1998) Peutz-Jeghers syndrome is caused by mutations in a novel serine threonine kinase. Nat Genet 18: $38-43$

Jiao W, Yakushiji H, Kitajima Y, Ogawa A, Miyazaki K (2000) Establishment and characterization of human hilar bile duct carcinoma cell line and cell strain. J Hepatobiliary Pancreat Surg 7: 417-425

Kang MS, Lee HJ, Ku JL, Lee KP, Kelly MJ, Won YJ, Kim ST, Park J-G (1996) Mutation of p53 gene in hepatocellular-carcinoma cell lines with HBX DNA. Int J Cancer 67: 898-902

Kim DG, Park SY, You KR, Lee GB, Kim H, Moon WS, Chun YH, Park SH (2001a) Establishment and characterization of chromosomal aberrations in human cholangiocarcinoma cell lines by cross-species color banding. Genes Chromosomes Cancer 30: 48-56

Kim YT, Kim J, Jang YH, Lee WJ, Ryu JK, Park YH, Kim SW, Kim WH, Yoon YB, Kim CY (2001b) Genetic alterations in gallbladder adenoma, dysplasia and carcinoma. Cancer Letts 169: 59-68

Kitaeva MN, Grogan L, Williams JP, Dimond E, Nakahara K, Hausner P, DeNobile JW, Soballe PW, Kirsch IR (1997) Mutations in beta-catenin are uncommon in colorectal cancer occurring in occasional replication error-positive tumors. Cancer Res 57: 4478-4481

Knuth A, Gabbert H, Dippold W, Klein O, Sachsse W, Bitter-Suermann D, Prellwitz W, Meyer ZNHK (1985) Biliary adenocarcinoma characterization of three new human tumor cell lines. J Hepatol 1: 579-596
1079) by RT - PCR analysis (Figure 5A). After demethylating agent (5-aza-2'-deoxycytidine) treatment, E-cadherin was successfully reexpressed in these two cell lines (Figure 5B). Hypermethylation of E-cadherin gene in two cell lines have also been confirmed by methylation specific PCR (MS-PCR) analysis (Figure 5C). These results would be the first report about hypermethylation of $E$ cadherin gene in biliary tract cancers.

Since the establishment of biliary tract cancer cell lines has been rarely reported in the literature, these well-characterised biliary tract cancer cell lines will be useful tools for investigating the biological characteristics of biliary tract cancer, especially those related to the hypermethylation of E-cadherin gene in biliary tract cancers.

\section{ACKNOWLEDGEMENTS}

This work was supported by the international cooperation program of the Korea Ministry of Science and Technology.
Kohno T, Shinmura K, Tosaka M, Tani M, Kim SR, Sugimura H, Nohmi T, Kasai H, Yokota J (1998) Genetic polymorphisms and alternative splicing of the hOGG1 gene, that is involved in the repair of 8-hydroxyguanine in damaged DNA. Oncogene 16: 3219-3225

Ku JL, Kim WH, Lee JH, Park HS, Kim KH, Sung MW, Park JG (1999) Establishment and characterization of human laryngeal squamous cell carcinoma cell lines. Laryngoscope 109: 976-982

Liu B, Parsons RE, Hamilton SR, Petersen GM, Lynch HT, Watson P, Markowitz S, Willson JKV, Green J, de la Chapelle A, Kinzler KW, Vogelstein B (1994) hMSH2 mutations in hereditary nonpolyposis colorectal cancer kindreds. Cancer Res 54: 4590-4594

Lu SL, Zhang WC, Akiyama Y, Nomizu T, Yuasa Y (1996) Genomic structure of the transforming growth factor beta type II receptor gene and its mutations in hereditary nonpolyposis colorectal cancers. Cancer Res 56: 4595 4598

Melki JR, Vincent PC, Brown RD, Clark SJ (2000) Hypermethylation of Ecadherin in leukemia. Blood 95: 3208-3213

Myeroff LL, Parsons R, Kim SJ, Hedrick L, Cho KR, Orth K, Mathis M, Kinzler KW, Lutterbaugh J, Park K, Bang YJ, Lee HY, Park J-G, Lynch HT, Roberts AB, Vogelstein B, Markowitz SD (1995) A transforming growth factor $\beta$ receptor type II gene mutation common in colon and gastric but rare in endometrial cancers with microsatellite instability. Cancer Res 55: 5545-5547

Orlow I, Lacombe L, Hannon GJ, Serrano M, Pellicer I, Dalbagni G, Reuter VE, Zhang ZF, Beach D, Cordon-Cardo C (1995) Deletion of the p16 and p15 genes in human bladder tumors. J Nation Cancer Inst 87: 1524-1529

Park J-G, Lee JH, Kang MS, Park KJ, Jeon YM, Lee HJ, Kwon HS, Park HS, Yeo KS, Lee KU (1995) Characterization of cell lines established from human hepatocellular carcinoma. Int J Cancer 62: 276-282

Park J-G, Oie HK, Sugarbaker PH, Henslee JG, Chen TR, Johnso BE, Gazdar AF (1987) Characteristics of cell lines established from human colorectal carcinoma. Cancer Res 47: 6710-6718

Saijyo S, Kudo T, Suzuki M, Katayose Y, Shinoda M, Muto T, Fukuhara K, Suzuki T, Matsuno S (1995) Establishment of a new extrahepatic bile duct carcinoma cell line, TFK-1. Tohoku J Exp Med 177: 61-71

Takiyama I, Terashima M, Ikeda K, Kawamura H, Kashiwaba M, Tamura G Suto T, Nakashima F, Sasaki R, Saito K (1998) Establishment and characterization of a new human extrahepatic bile duct carcinoma cell line (ICBD-1). Oncol Rep 5: 463-467

Vincent F, Nagashima M, Takenoshita S, Khan MA, Gemma A, Hagiwara K Bennett WP (1997) Mutation analysis of the transforming growth factorbeta type II receptor in human cell lines resistant to growth inhibition by transforming growth factor-beta. Oncogene 15: 117-122

Williamson MP, Elder PA, Shaw ME, Devlin J, Knowles MA (1995) p16(CDKN2) is a major deletion target at 9p21 in bladder cancer. Hum Mol Genet 4: 1569-1577 
Yamada N, Chung YS, Arimoto Y, Sawada T, Seki S, Sowa M (1995) Establishment of a new human extrahepatic bile duct carcinoma cell lines (OCUCh-LM1) and experimental liver metastatic model. $\mathrm{Br}$ J Cancer 71: $543-548$

Yamada N, Chung YS, Ohtani H, Ikeda T (1997) Establishment and characterization of a new human gallbladder carcinoma cell line (OCUG-1) producing TA-4. Int J Oncol 10: $1251-1257$

Yano H, Maruiwa M, Iemura A, Mizoguchi A, Kojiro M (1992) Establishment and characterization of a new human extrahepatic bile duct carcinoma cell line (KMBC). Cancer 69: 1664-1673
Yazumi S, Ko K, Watanabe N, Shinohara H, Yoshikawa K, Chiba T, Takahashi R (2000) Disrupted transforming growth factor-beta signaling and deregulated growth in human biliary tract cancer cells. Int J Cancer 86: $782-789$

Yoshida S, Todoroki T, Ichikawa Y, Hanai S, Suzuki H, Hori M, Fukao K, Miwa M, Uchida K (1995) Mutations of p16Ink4/CDKN2 and p15Ink4B/MTS2 genes in biliary tract cancers. Cancer Res 55: 2756-2760 